\title{
DOCUMENTS
}

H. Kendall Rogers

\section{EDUARD BERNSTEIN SPEAKS TO THE FABIANS: A TURNING-POINT IN SOCIAL DEMOCRATIC THOUGHT?}

Of Eduard Bernstein's many writings surely few were as significant in the early development of revisionism as his speech to the London Fabian Society on January 29, 1897. In an October 1898 letter to August Bebel, Bernstein described the gradual metamorphosis that had led to his heterodox views. Until October 1896 he had sought to "stretch" Marxist theory to conform to social-democratic practice; finally he realized this was impossible.

Bezeichnender od. auch begreiflicher Weise, wurde mir das Unmögliche dieses Vorhabens erst völlig klar, als ich vor anderthalb Jahren, im Verein der Fabier einen Vortrag darüber hielt, "Was Marx wirklich lehrte". Ich habe das Manuskript des Vortrages noch, es ist ein abschreckendes Beispiel wohlmeinenden "Rettungsversuchs". Ich wollte Marx retten, wollte zeigen, daß alles so gekommen was er gesagt, und, daß alles, was nicht so gekommen, auch von ihm gesagt wurde. Aber als das Kunststück fertig war, als ich den Vortrag vorlas, da zuckte es mir durch den Kopf: Du thust Marx Unrecht, das ist nicht Marx, was Du vorführst. Und ein paar harmlose Fragen, die mir ein scharfsinniger Fabianer Hubert Bland nach dem Vortrag stellte und die ich noch in der alten Manier beantwortete, gaben mir den Rest. Im Stillen sagte ich mir: so geht das nicht weiter. ${ }^{1}$

For some historians Bernstein's Fabian lecture was the point where he turned decisively against Marxism. For those who date Bernstein's repudiation of Marx from Engels's death, the address at least marked the point where Bernstein realized how thoroughly he had already broken with Marxist orthodoxy. ${ }^{2}$ And for all students of pre-war social-democratic

1 Bernstein to Bebel, October 20, 1898, in: Victor Adler, Briefwechsel mit August Bebel und Karl Kautsky, ed. by Friedrich Adler (Vienna, 1954), p. 260.

2 See, for example, H. Hirsch, Der "Fabier" Eduard Bernstein. Zur Entwicklungsgeschichte des evolutionären Sozialismus (Bonn, 1977), p. 36; id., "Die bezüglich der Fabian Society transparenten Kommunikationsstrukturen als Teilaspekte der internationalen Voraussetzungen zur Herausbildung des Revisionismus von Eduard Bernstein", in: Bernstein und der Demokratische Sozialismus, ed. by H. Heimann and Th. 
theory, the actual text of the speech could provide valuable insight into Bernstein's thought in January 1897, midway between Engels's death in August 1895 and Bernstein's controversial letter to the Stuttgart Congress in October 1898. Accordingly, Helmut Hirsch has searched for the missing Fabian address, and he has published both a newspaper announcement of the lecture and a review of it, the latter possibly written by George Bernard Shaw. ${ }^{3}$ Now, however, an almost complete text of the original speech is available, thanks to the fact that Bernstein edited and published it as the article "Karl Marx and Social Reform" in The Progressive Review, May $1897 .^{4}$

The correspondence of Bernstein with Karl Kautsky constitutes the first type of evidence that the Progressive Review article was in fact the Fabian address. These letters also suggest that the speech in part originated in the bitter polemical battle which Bernstein and Kautsky waged in the latter half of 1896 against Ernest Belfort-Bax and H. M. Hyndman of the British socialist movement, against the democratic editor Heinrich Kanner in Vienna, and especially against Wilhelm Liebknecht in Germany. After finishing a devastating review of Hyndman's The Economics of Socialism, ${ }^{5}$ Bernstein wrote Kautsky on September 23, 1896, to propose an article for Die Neue Zeit on the question "War Marx ein Marxist?" Bernstein intended, "mich über das Verhältniß des Schülers zum Meister etwas auszulassen, d.h. zu zeigen, daß eine Theorie aufnehmen und auf Grund ihrer weiter arbeiten etwas ganz andres ist als nachbeten". ${ }^{6}$ Liebknecht as well as Hyndman followed Marx in this simplistic manner; so at the same time, Bernstein launched an attack on Liebknecht's interpretation of the crisis in Turkey, this interpretation being merely a summary of certain statements made by Marx during the Crimean War. ${ }^{7}$ On September 25 Kautsky replied to Bernstein that he would appreciate an article on "War Marx ein Marxist?"8 Perhaps Kautsky found the topic particularly appropriate just at the time he was debating Bax, who had accused Kautsky of

Meyer (Bonn, 1978), p. 51; and Th. Meyer, Bernsteins konstruktiver Sozialismus. Eduard Bernsteins Beitrag zur Theorie des Sozialismus (Bonn, 1977), pp. 32f. and particularly note 132 , p. 33.

${ }^{3}$ Hirsch, Der "Fabier" Eduard Bernstein, pp. 121-23.

4 Bernstein, "Karl Marx and Social Reform", in: The Progressive Review, II (1897), pp. $140-54$. The article is reprinted with its numerous inconsistencies.

${ }^{5}$ Bernstein, "Sozialistische Oekonomie in England", in: Die Neue Zeit, XV (1896-97), 1, pp. 46-54.

6 Kautsky Papers DV 384, Internationaal Instituut voor Sociale Geschiedenis.

7 See, for example, Anon. [Bernstein], "Die Agitation gegen die türkische Misswirthschaft", in: Vorwärts, 29 September 1896, p. 3.

8 Kautsky Papers C 148. 
vulgar economic determinism and had cited Marx's famous saying "Moimème je ne suis pas Marxiste." But then on September 26 Kanner again attacked Kautsky in the Vienna weekly journal Die Zeit. Kanner appealed to an article by Shaw in Cosmopolis which blamed the German Social Democratic Party for professing a violent, revolutionary theory in stark contradiction to its peaceful, reformist practice. ${ }^{10}$

On October 5 Bernstein wrote Kautsky to explain why Shaw and the other Fabians so completely misunderstood Marxism: "Sie sind im guten u. schlechten Sinne reine Empiriker und nehmen auch den Marxismus rein empirisch, wie er ihnen in Gestalt von Hyndman, Liebknecht, Avelings entgegentritt. Sie wissen nicht, daß dieser Marxismus sehr unmarxistisch ist, oder vielmehr, wie sehr er es ist." Accordingly, Bernstein abandoned his proposed article for Die Neue Zeit and decided instead to write an essay for The Progressive Review in order to answer Shaw and to show that Marxism could not be identified with the ideas of Hyndman and Liebknecht. ${ }^{11}$ In the meantime, on October 2 the executive committee of the London Fabian Society had asked Bernstein to lecture on the topic "Marxism, True and False"; later they agreed to "What Marx Really Taught". ${ }^{12}$ Both titles revealed the intention of proving a fundamental difference between the Marxism of Engels, Kautsky and Bernstein, and the interpretation of Marx espoused by Liebknecht, Bax and Hyndman. Little could be more understandable than that Bernstein would write the Fabian speech with the Progressive Review essay in mind and that he would also seek to deal with issues he had initially wanted to raise in "War Marx ein Marxist?" When the article "Karl Marx and Social Reform" did finally appear in May 1897, Bernstein wrote Kautsky that it was the Fabian address and that it restated the theory of historical materialism. ${ }^{13}$

Several newspaper accounts form the second category of evidence that Bernstein's speech to the Fabian Society later appeared in The Progressive Review. The newspapers list the lecture's key points; and these correspond almost exactly to the key points of the article "Karl Marx and Social Reform". In addition to the two documents published by Hirsch, there exist a review of Bernstein's Fabian address in Justice, 6 February 1897, p. 8 , and a response by Bernstein in Justice, 13 February, p. 3. The original

9 E. Belfort-Bax, “Die materialistische Geschichtsauffassung”, in: Die Zeit, VIII (1896), p. 20 , note.

10 H. Kanner, "Kleine Gernegrosse", ibid., pp. 193-95; G. B. Shaw, "Socialism at the International Congress", in: Cosmopolis, III (1896), pp. 658-73.

11 Kautsky Papers DV 385 and 388.

12 Hirsch, Der "Fabier" Eduard Bernstein, p. 35, note 43, and p. 36.

${ }^{13}$ Kautsky Papers DV 412. 
report for Justice contains phrases which appear again in The Progressive Review. Bernstein's reply to Justice includes quotations from the Fabian lecture, and the quoted passages are also in "Karl Marx and Social Reform". By comparing the four newspaper accounts with the Progressive Review article, one can surmise the editing Bernstein performed to prepare the address for publication - omitting some material, but adding a new introduction and conclusion. Such changes are noted in the text of "Karl Marx and Social Reform" printed below.

Now that Bernstein's Fabian speech is available, one may re-evaluate its significance in the evolution of revisionism. By the time of his letter to Bebel in October 1898, Bernstein had been engaged in acrimoneous debates for eight months against the key leaders of the socialist left Parvus, Rosa Luxemburg, George Plekhanov. Finally even Kautsky spoke against Bernstein at Stuttgart. The letter to Bebel accurately reflected Bernstein's embittered attitude toward Marxism; but this attitude was more characteristic of his thought after these polemics than of his Fabian address long before them. During the twenty months from January 1897 to October 1898, Bernstein had forgotten the original purpose of the lecture: to contrast a vulgar distortion of Marx with the mature Marxism of Engels and Kautsky. In the Fabian speech Bernstein had not tried to "stretch" Marxism to make it conform to the actual practices of German Social Democracy; rather, he had opposed a misinterpretation of Marx which created the illusory contradiction of theory and practice. ${ }^{14}$ Bernstein had not sought to justify each prediction Marx made; rather, he had argued the true Marxist searched for political and social changes in agreement with actual material conditions rather than in accord with a preconceived plan. The Fabian address provided a point-by-point refutation of the vulgarization of Marx propagated by Liebknecht, Hyndman and Bax; Bernstein also attacked Shaw and Bertrand Russell for so uncritically accepting this false interpretation as an accurate portrayal of what Marx had really taught. Presumably, at the time Bernstein was pleased with his lecture defending Marxism against distortion. If not, then why did he publish it?

The Fabian speech, then, formed an integral part of Bernstein's work in the months immediately preceding the revisionist controversy. In the years 1895 through 1897, when Engels was no longer present to determine what Marx had actually meant, Bernstein and Kautsky together fought to

${ }^{14}$ Compare Bernstein's criticism of Bertrand Russell for discovering a contradiction between the theory and practice of German Social Democracy only because Russell misunderstood Marxism to begin with. This is in Bernstein, "Die deutsche Sozialdemokratie in englischer Beleuchtung”, in: Die Neue Zeit, XV/1, pp. 433-35. 
defend a mature interpretation of Marxism against a simplistic popularization of it propagated by Liebknecht in Germany and by his followers in the Social Democratic Federation in England, especially Hyndman and Bax. Where the former interpretation called for gradual social evolution, a parliamentary transition to proletarian rule in countries which had had a bourgeois revolution, and acceptance of capital's expansion abroad, for example, the latter view anticipated sudden social change, assumed violent political revolution even in England, and urged native resistance to European colonialism. Most importantly, Kautsky and Bernstein understood Marxism to be a method for analyzing actual social and political change, while their opponents saw Marxism as a set of dogmas about how history would necessarily occur.

The struggle between these two interpretations occurred over many specific issues: English domestic politics, British imperialism in Africa, philosophical implications in the writing of history, the agrarian question, Polish independence, which demands social democrats should make given the economic and constitutional development of Germany, participation in elections to the Prussian and Saxon Diets, and especially the crisis in the Ottoman Empire. In order to interpret Bernstein correctly, it is helpful to remember that many of his central ideas first appeared in essays written directly against Liebknecht or members of the Social Democratic Federation. In addition to the Fabian speech, such writings included Bernstein's Probleme des Sozialismus series, his afterwords to the books by Héritier and the Webbs, his major articles in Die Neue Zeit, and numerous statements in Vorwärts or in letters to editors of various English and German periodicals. Not surprisingly, the battle was frequently mentioned in Bernstein's correspondence with Kautsky. However, through the vehemence of the controversy, by August 1897 Bernstein had come to identify "Marxism" with the very misinterpretation against which he and Kautsky had once fought to defend Marx. ${ }^{15}$

Liebknecht particularly appealed to earlier ideas of Marx. In debates on Turkey in 1896, Bernstein as well as Kautsky and Luxemburg argued that this was invalid; all three believed that Marx's views on the Eastern Question were no longer relevant, even if they had been sound in the 1850 's. ${ }^{16}$ The Fabian speech was significant because for the first time

15 See my doctoral dissertation, "Before the Revisionist Controversy: Kautsky, Bernstein, and the Meaning of Marxism, 1895-1898" (Ph.D. diss., Harvard University, 1984). 16 See, for example, W. Liebknecht, "Erklärung", in: Vorwärts, 11 November 1896, p. 4; R. Luxemburg, "Zur Orientpolitik des 'Vorwärts", in Gesammelte Werke (Berlin, 1970-75), I/1, pp. 69-73; Bernstein, "Die deutsche Sozialdemokratie und die türkische Wirren", in: Die Neue Zeit, XV/1, pp. 112-15; and Kautsky to Bernstein, October 7, 
Bernstein sought to defend a mature Marxism and reject the distorted version by publicly confessing that certain, earlier ideas of Marx were not only outdated, but had also been wrong when Marx first had them. Bernstein felt particularly justified in saying this because both Marx and especially Engels had admitted they had been mistaken. In his address to the Fabian Society, Bernstein did not turn against Marxism; neither did he discover how far he had broken with Marx already; rather, he first used Engels's 1895 "Introduction" to Marx's The Class Struggles in France to argue that a true Marxist should independently follow historical materialism even if this led to results contradicting Marx's own conclusions. The method of Marx and Engels "held good all the time" even if its creators sometimes reached false conclusions based on inadequate information. That one must understand Marxism as a method of research, and not as a set of results, was what Bernstein had first intended to say in his article "War Marx ein Marxist?"

\section{KARL MARX AND SOCIAL REFORM}

To the average Englishman Karl Marx is in regard to social politics an ultra-revolutionary state-socialist, the advocate of violent overthrow of all constituted order in government. Considering the great influence Marx and his school of thought hold upon the Socialist labour movement of to-day, it may not seem untimely to investigate how far this impression is justified.

What was Marx's position to social reform? In putting the question thus, we have at once to contend with a difficulty. Marx during his life wrote a great deal, and, of course, also learned a great deal. Which of his writings represent the living Marx? The great mass of friends and foes alike treat a quotation from the "Manifesto of the Communists" in the same way as a quotation from "Das Kapital". They adjudge to them quite the same value, as high or as low as their estimation of Marx may be.

Now it is certainly true that from about 1846 there runs through all writings of Marx an identical line of thought. His conception of social

1896, Kautsky Papers C 151. In this letter Kautsky explained: "Meiner Ansicht nach ist die alte Marxsche Orientpolitik unhaltbar geworden." The change in Bernstein's thinking marked by the Fabian speech was reflected in his letter to Kautsky on March 10, 1897, where Bernstein argued that Marx was originally mistaken on the Eastern Question. This latter letter is in the Kautsky Papers DV 406. 
evolution and of the historical mission of the modern proletariat, as laid down in the Manifesto, until the last underwent no change in principle. But for our purpose it is not only the general principle we have to consider, but also the application given to it by Marx in regard to questions of the day, its relation to time and ways and means. To assume that also in this respect Marx's ideas underwent no change at all, would mean that he was either a god or a madman. Yet of those who admit or proclaim that he was one of the greatest thinkers of our era a great many treat him in a way as only such assumption would justify. ${ }^{17}$

It is curious indeed how sensible people have not hesitated a moment to put into the mouth of a man whose keen intellect they profess to admire, the most idiotic nonsense. In his otherwise praiseworthy book on German Social Democracy, Mr. Russell, e.g., says of Marx: "In his views of human nature he generalised the economic motive, so as to cover all departments of social life", and "there is no question, in Marx, of justice or virtue, no appeal to human sympathy or morality, might alone is right" (l.c., p. 8 and 14). If this were true, Marx as a social philosopher would be convicted at the outset. But it is an absolutely mistaken notion of the trend of Marx's theory. Mr. Russell could with as much right have said that in Darwin's theory of the struggle for life there was no question of paternal love or tribal co-operation amongst animals.

Marx's social theory is based on what he has called historic materialism, a conception of history worked out by himself and Frederic Engels in the forties of this century. According to it the ultimate forces in the evolution of social life, the ultimate causes that determine the evolution of morals are of an economic nature; they are to be found in the changes of the modes of production of the necessaries of life. To a given mode of production and exchange of the necessaries of life, correspond certain forms of social institutions and moral conceptions, and they will prevail as long as the former continues to exist, though not always in their purity or in absolute sway, as they have to contend with remainders of former institutions and

17 These opening paragraphs probably did not appear in the original speech; rather, Bernstein added them for publication. Apparently Bernstein began his Fabian address by stating bluntly that Marx's writings had been read in a biased fashion. Academics claimed he was a genius only to inflate their own importance for tearing him to pieces. However, the Marx whom these intellectuals ridiculed and whom fanatic socialists praised was in fact a straw man, a caricature of the true Marx. Since the false understanding of Marxism had advocates as well as opponents, it was important to find out just what Marx had really taught. Though this had been misunderstood in respect both to theory of history and to economics, Bernstein felt he had time only for the former. Accordingly, he deleted a presentation on Das Kapital, Vol. III, which might have followed his recent attack on Hyndman's economics. 
the germs of a slowly evolving new mode of life, factors which call forth a certain variety such as everywhere we observe in nature. But in every period of history we can easily distinguish a prevailing mode of production and exchange, and a corresponding conception of life, and of duties and rights, which also prevail and determine the nature of the social and political institutions of the period. This is quite obvious in the earlier stages of social life. But the more complex society becomes, the more will the objective causes of social evolution recede into the background, and subjective ones appear to determine its course. But, powerful as the subjective factor is in history, it is still under the control of the working of the economical foundations of social life.

It is in this sense that Marx says in the preface to "Das Kapital": -

Even when a society has got upon the right track for the discovery of the natural law of its evolution, it can neither jump over normal phases of its development, nor can it remove them by decree. But it can shorten and alleviate the pains of child-birth.

People have stigmatised the materialistic conception of history as historic fatalism. But they have, as yet, not been able to point out a country where production on commercial lines and feudal law and morals are co-existing in full vigour.

We have seen progressive movements, upheld by most energetic men, entirely collapse for no other reason than because they anticipated a state of social evolution which had not yet set in. On the other hand, wherever the industrial development has reached certain points, it has called forth social movements which, if different in garb, according to special geographical conditions, are in substance alike in all countries. Twenty years ago a whole generation of heroic youths risked freedom and life in Russia to bring about a social revolution. They were sacrificed in vain; the material premises of their idea did not exist. Semi-Asiatic conditions of life prevailed in the greater part of the country. Since then an increasing number of factories has been built, new railways have been constructed, the traffic increased, modern commerce extended all over the country, trade enormously expanded. These economical changes have revolutionised the brains of the people more than all the pamphlets and leaflets written in glowing terms and distributed broadcast by the young heroes who risked freedom and life for a generous ideal. To-day it is admitted on all sides that Russia has her own labour-movement. The dream, fostered by men like Bakunin, of saving the Russians the period of bourgeois-economy is done with for ever; neither can the all-powerful Tsar - to speak with Marx - remove it by decree, nor can the fiery revolutionist make Russia jump over its phases of evolution with the aid of dynamite. 
In short, there is what we Germans call Gesetzmässigkeit - an order of law - in social evolution. Marx has formulated the main principles of it in his Criticism of Political Economy, published in 1859, as follows: -

A formation of society will not disappear until all productive forces are evolved for which it is wide enough, and new and higher systems of production will never be installed until the material conditions of their existence are hatched out in the very bosom of the old society. Hence humanity always sets itself only to solve problems it is capable of solving; for if you examine things closer you will always find that the problem arises only where the material premises of its solution exist already, or are at least in the process of being formed.

So much for the objective side of social evolution. The main subjective lever of it is, as long as society is divided into classes, the class-antagonism or class-war. It has been said that, if such a thing has existed in former ages, it does not exist in advanced modern society, in our enlightened era of liberal or democratic institutions, and facts are extant in this country which indeed seem to disprove the whole theory of the class struggle. Do we not see the great mass of the workers in England appallingly indifferent towards any social reform movement which does not bear upon their individual and immediate interest? Is it not the visible result of the social inertia of the workers that labour questions have taken a back seat in Parliament, and would stand even still more in the background but for the great number of middle-class reformers.

The facts, themselves, cannot be denied, but they do not disprove the class-war theory as put forward by Marx; they only disprove some crude and narrow interpretations of it.

First of all there are different forms of warfare. "The process of revolution", writes Marx, in the preface to Das Kapital, "will take more brutal or more human forms, according to the degree of development of the workers". Now a great section of the wage-earners of this country have quite evidently made steady progress in regard to their social conditions. No wonder that they prefer what are called constitutional methods to the more violent forms of warfare. But, safe as this way is, it is not likely to arouse the passionate enthusiasm of the masses. ${ }^{18}$ Another reason of the apparent inertia of the workers in England, is perhaps just to be found in the fact that so many middle-class people have taken up social reform. To some extent this daily increase of middle-class reformers may be ascribed

18 Here Bernstein apparently deleted a passage from the original speech which suggested that the British labor movement might be more radical if an earthquake swallowed men like Shaw and Webb, Haldane and Dilke - members of the non-proletarian classes who nonetheless sought to serve working-class interests. 
to a growing sense of social duty, although the growth itself again is an effect of, in the last instance, economical causes. But a much stronger force than the more or less ideological motives that have induced people in middle-class position to take up the cause of social reform, is the change the franchise reform has brought about in the political life of this country.

It is not a little surprising how indifferent many English Socialists are in regard to questions of the suffrage, so that a very influential labour leader could two or three years ago refuse to take part in an agitation for universal suffrage - not because it was inopportune, but that it was "mere radicalism". In form, of course, it is, but with an adult population consisting in its majority of industrial wage-earners it is in substance more than that. Proudhon saw deeper when he declared that universal suffrage was incompatible with the subordination of labour to capital. And it is known what Lord Palmerston said of the changes Lord John Russell's Franchise Reform of 1860 would bring about in regard to the House of Commons. "I dare say, the actors will be the same, but they will play to the galleries instead of to the boxes." So far, history has not disproved his fears.

To-day the member of Parliament plays for an audience, the majority of which in most cases are workers, and he plays accordingly. There are very few of them who have not taken up at least one question of real or fancied interest to the workers as their speciality, from the legal eight hours day to "England for the English". Any question which a large section of the workers have at heart is sure to find a great number of advocates in the ranks of the middle-class legislators. All this gives the class-struggle another form.

It works to-day more as a potential than as an active force, more by the knowledge of what it might be than by actual manifestation. Politically as well as economically it is fought by sections or divisions, and often in forms which are the reverse of what they ought to be according to the letter, so that it might appear as if it were not the social classes that contest with one another the control of legislation, but rather the legislators that fight for the satisfaction of the classes. But the class struggle is no less a reality because it has taken the shape of continuous barter and compromise. ${ }^{19}$

Marx's book "Zur Kritik der Politischen CEkonomie" appeared in 1859, the same year when Darwin's "Origin of Species" was first published. Marx has often been compared with Darwin, and, in my opinion, very justly so. That Marx from the beginning took the greatest interest in Darwin's researches, there is not the slightest doubt. A letter of Lassalle to Marx of

19 As other reasons for the peculiar development of class conflict in England, in his original speech Bernstein here mentioned emigration and the need for capital to conquer new worlds before it was finished. 
the year 1859, shows that Marx had called Lassalle's attention to the "Origin of Species" as soon as the book had appeared. And, curiously enough, amongst the left manuscripts of Marx and Engels, I have come across one written not later than 1847 , where I found a most remarkable passage pointing out with great vigour the struggle for life in nature. Of course, the term is not used, but the thing is clearly presented, and at the end we meet the following striking sentence: "Hobbes could have founded his 'bellum omnium contra omnes' with greater right on nature than on men".

This, only by the way. But, from all said, so far, it is quite evident that Marx's theory is eminently evolutionary. Now evolution is, as the "British Review" recently said, "a very comfortable word". You can, indeed, use it in the most Pickwickian sense. You can oppose it to revolution, you can construct an absolute contradiction between evolution and revolution. To Marx, evolution included revolution and vice versa; the one was a stage of the other. Not every revolution must be violent or sanguinary. But, besides those brought about by industrial changes alone, we have those phases of social evolution, which take the shape of, or are brought about by, political revolutions. They, too, have their drawbacks, undoubtedly, but they have also their advantages - they clear away in a day the dust and the rubbish that else would take generations to remove - they are, in the words of Marx, the locomotives of history. They are also mostly attended by a great intellectual impulse. Thousands of slumbering intellects are stimulated, wits are sharpened, ranges of sight widened. And when it so comes to violent struggle, then, of course, might is right - as it has been in 1648, in 1793 , in 1830 , and in 1848 . By that I do not mean to say that might was always "justice".

Marx, then, was, if you like to put it thus, a revolutionary evolutionist. But he was far from revolutionary romanticism. I doubt whether he would have subscribed to the sentence, that in the natural philosophy of Socialism light is a more important factor than heat, but I am sure he would not have subscribed to the contrary, that heat was more important than light. Indeed, in a declaration against a section of the Communistic League, which then cultivated a very heated revolutionarism, Marx said in September, 1850 - and I think these words ought not to be forgotten: -

The minority puts into the place of the critical a dogmatic conception. To them not real existing conditions are the motive force of revolution, but mere will. Whilst we tell the workers, you must run through 15, 20, 50 years of civil wars and struggles, not only for changing the conditions, but for altering yourselves and for rendering yourselves capable of political supremacy, you, on the contrary declare: "We must at once capture power, 
or we may go and lay down to sleep". Whilst we explain, especially to the German workmen, how undeveloped the proletariat is in Germany, you flatter in the coarsest way the national sentiment and the sectional prejudice of the German handicraftsmen - a process which, true, is more popular. Just as the Democrats have made the word people, so you have made the word proletariat a fetish. Just like the Democrats, you substitute the revolutionary phrase for the revolutionary evolution.

Here the question may be raised how this evolutionist conception agrees with the concluding words of the Communist Manifesto, that the ends of the Communists "can only be attained by the forcible overthrow of all existing conditions". To this the first reply is that the Manifesto was written on the eve of a Revolution - the Revolution of 1848 - which, indeed, overthrew forcibly a good deal of the existing social conditions. The comparative youth of the movement, and, I may add, the youth of the writers themselves, as well as the very political situation of the time, explains the accentuation of revolutionary violence. Besides, the Communist Manifesto had a polemical purpose - to fight the enervating communism of universal love then flourishing in Germany. It had to educate the workers for the impending political struggle which was sure to take revolutionary form. At the same time as Marx and Engels wrote these lines they, however, strongly opposed all playing with conspiracy. Putting educational propaganda in the place of conspiracy was the condition of their joining the League of the Communists.

But it shall not be denied - Engels himself has it in one of his last publications expressly stated - that Marx and he in 1848 greatly overestimated the state of industrial evolution attained. They believed the breakdown of bourgeois civilisation to be within hail, if, however, to be worked out in a prolonged series of revolutions. And in their over-estimation of the state of social evolution they were even less sanguine than other Socialists of the time. "We all were firmly convinced", Bakunine later said to Benoit Malon, "that we were living the last days of the old society". The year 1848 brought the great disappointment. How Marx understood its lesson the speech made in 1850 has shown. In our appreciation of the quickness of social movements we are always subject to error, and may have continuously to correct ourselves, whilst our theory holds good all the time.

If his theory did not always protect Marx from a too sanguine view of the march of events, it, on the other hand, obliged him to propose nothing which was not based on a close study of actual conditions. He strongly resisted temptations to prescribe remedies for the future. To study the given economic conditions of society, to closely follow their march, to 
ascertain what to do - not from an imaginary perfect Socialist world, but from the very imperfect world we live in and its actual requirements - is therefore the task of the disciples of Marx. People may repeat in eloquent terms the general doctrines of the class war, and speak again and again of the social revolution and the socialisation of all the means of production, exchange, and distribution - they will still be poor Marxists if they refuse to acknowledge changes in the economical evolution which contradict foimer assumptions, and decline to act accordingly.

But better than all general deductions a rapid survey of Marx's own public life will illustrate the true sense of his social theory.

Marx and Engels had worked out their theory in the years 1845 and 1846. The literary controversies in which they affirmed it form one of the most interesting and most instructive chapters in the history of Socialism. As early as that time both men were in intimate relation with the fighting representatives of advanced Democracy in different countries - Chartists in England, Radical Social Reformers in France, Democrats in Belgium.

In Germany there were then not even great political middle-class parties formed: the whole political struggle was almost exclusively fought in newspapers and other prints. But just because the fight was a literary one a tremendous amount of Radicalism was displayed. Germans believed themselves much superior to English and French. They imagined they could do without those petty institutions these had to try, just as a generation later the Russians did with respect to the same nations Germany now included. Marx and Engels very soon overcame this superstition, and strongly opposed those Socialists who imported from England and France the condemnation of Parliamentarianism. They showed that this ultra-Radicalism was in fact Reaction: the bourgeois liberties had first to be conquered and then criticised.* They proclaimed that the Communists had to support the bourgeoisie wherever it acted as a revolutionary progressive class. When, therefore, the Revolution of 1848 broke out, Marx and Engels, instead of preaching Communism in a small private sheet, preached Radical action in a comparatively widely circulated paper they had founded in conjunction with advanced political Democrats - the famous "Neue Rheinische Zeitung".

Fighting on political lines did, however, not mean neglect of economical questions. Just the reverse. In the "Neue Rheinische Zeitung", amongst

* See the section, "The German or 'true' Socialism," in the "Manifesto of the Communists" (London, Reeves). This section gives in a condensed form the polemics of Marx and Engels against contemporary Socialists. 
others, the case of the peasants against the feudal classes was advocated most energetically, and there Marx published his lectures on wage-labour and capital, and took in all real struggles the side of the workers.

In May, 1849, the paper was suppressed. Marx and Engels first resolved to go to South Germany, where a last battle was fought between the Revolution and the Reactionary Governments. Whilst they in no way shared the political ideas of the South German Democrats, they were for saving what was to be saved for Democracy. But the battle was lost, and both had to emigrate.

In London they tried to reorganise the Communist League. Like other Revolutionaries, they first hoped that a reconquest of their position by the French Radical Democrats would revive the revolutionary movements all over Europe. But soon they recognised that this hope was not well founded, and they opposed all movements amongst the German emigrants of forming leagues for revolutionary attempts. The hatred they drew upon themselves by this was without bounds, and results of the campaign of slander waged against them by men, many of whom afterwards became obedient Bismarckians, can even be traced in our own days. It was then that Marx, because he declined to support an illusion which could only exact useless sacrifices, was declared a cold, calculating scribbler and system-maker, who had not a bit of feeling for the people; no heart, only reason; no heat, only dry - too dry - light.

His reply, or part of it, to such accusations we have given above. In a review then published by him he explained how commercial prosperity had set in, and that, with trade everywhere brisk, no general revolutionary rising was to be expected. "Such revolution", he added, "is only possible in times when there exists a conflict between those two factors, the modern forces of production and the bourgeois forms of production". Even the reaction did not know how strong the foundations of bourgeois civilisation were. "Against this condition of things", he added, "all attempts of reaction which aim at hampering bourgeois evolution will fail as surely as all the moral indignation and enthusiastic proclamations of the Democrats".

Instead of devoting himself to emigration politics, Marx, whilst working hard, at a miserable pay, for his livelihood, and studying in the British Museum, supported what was left of the Chartist movement by gratuitous contributions to Ernest Jones's papers, and lectured on social economy and other topics to a small nucleus of German workers. During the American civil war he took energetically the side of the anti-slavery States, and readers of "Das Kapital" know how severely Marx censures Carlyle's super-criticism of this - to use his own words - "most imposing historical event". 
The sixties saw the setting on foot of the International Working Men's Association, with Marx as its leading inspirer. When, somewhat later, the English Reform League was founded, an alliance of labour representatives and advanced Radicals for the purpose of pressing the then discussed Electoral Reform, the International, far from denouncing this "compromise", supported it, and the General Council, in a report to the International Congress of 1867 , referred with a certain pride to the fact that some of its members were most active members of the Council of the League.

The inaugural address and the statutes of the International are from the pen of Marx. They are proofs of his unsectarian mind. He made them wide enough to be acceptable to all sections of the labour movement, and still precise enough to give the movement a distinct, well-defined class character. The emancipation of the working classes must be accomplished by the workers themselves, but it is no movement for new class monopolies and privileges; it is not a local or national, but a social problem embracing all countries, where modern society exists. Every political movement is only to be regarded as a means subordinate to the great end of economical emancipation. Truth, justice, and morality shall rule the relation of the societies and individuals without regard to colour, creed, or nationality no rights without duties, no duties without rights.

To him who is unable to detect in works like "Das Kapital" appeals to human sympathy and morality, the rules of the International may be a proof that there was even with Marx a question of morality and justice, of duties and of love of man.

The first years of the International went comparatively smoothly enough. The first congresses framed resolutions - most of them drafted or suggested by Marx - in favour of technical and intellectual education, factory laws, trade unionism, co-operative societies, nationalisation of the means of transport, of mines and forests, and, later also, of land in general. But you read nothing of conspiracies and similar enterprises. The first international action which the council suggested was - an independent inquiry made by the workers themselves into the conditions of labour.

Then came the Paris Commune. The dissensions amongst the different French groups had already at an early time given a good deal of trouble to the General Council. After the downfall of the Commune they came to such a pitch that they took nearly all its time. Sections first invoked the authority of the Council, and when it was refused accused the Council of autocracy: Bakounine with his Anarchistic agitation aiding, the International broke up. A rival International created by Bakounine and his friends fared no better, in spite of its orthodoxy. 
Was the International a failure? Yes, and no. It failed so far as it undervalued the difficulties of international co-operation. But it was nevertheless a most powerful intellectual lever: its propagandist influence was enormous. In one case at least it helped to prevent war; and if it could not prevent the disastrous Franco-German war, it fostered demonstrations against it in France and Germany which afterwards had the most beneficial effect.

The two Manifestoes of the International on the war are both written by Marx. Still of greater interest, perhaps, than these is a letter on the war Marx wrote in September, 1870, to the Council of the German Social Democratic party. There - three days after the battle of Sedan - he predicted as the necessary consequence of the then proposed forcible annexation of Alsace-Lorraine the Franco-Russian Alliance and Russia's predominance in Europe. Those who in Germany clamorously demanded the annexation were, he says, either knaves or fools. Events have shown that these words were hardly too strong.

In the same letter, however, Marx recognises that by the German victories one result at least was obtained for the German workers. "Things will develop", he says, "on a great scale and in a simplified form. If the German working classes, then, will not play an appropriate part, it will be their own fault. This war has shifted the centre of gravity of Continental labour movements from France to Germany. Greater responsibility rests, therefore, with the German working classes".

Marx has often been painted as an embittered and soured emigrant. Little confirmation is given to such assertion by this letter, written, I repeat, three days after the battle of Sedan. (It was at the time inserted in a proclamation issued by the committee of the German Social Democratic party.)

Marx's position to trade unionism is illustrated by the resolution of the International strongly advocating trade organisation of the workers. As early as 1847 he had, in his book against Proudhon, taken sides for trade unionism, at a time when nearly all Continental and many English Socialists were dead against it.

With regard to co-operation, Marx shared the general preference of nearly all Socialists for co-operative production against mere distributive societies. And this is not surprising if you consider the narrow, dividendhunting spirit displayed for a long time by most distributive associations. Still Marx acknowledged their importance, if independent from State and bourgeois direction, as being examples of the superfluity of the exploiting capitalists and useful means of strengthening the position of the workers. But he emphasised their insufficiency, in face of the enormous means of 
capitalist society, for revolutionising the whole industrial world. It was impossible, according to him, to bring about a whole revolution of society behind the back of that society, so to speak. For this end the very means and weapons of society were to be made use of.

And this leads to the much discussed question of Socialism and State influence. Marx has been described alternatively as a hard and fast State Socialist, and as an anarchist opponent to State Socialism; as a rigid centralist, and as an ultra-federalist. In fact he was neither the one nor the other. He neither shared what he mockingly called the belief in State miracles, nor did he share the superstitious fear of the State. ${ }^{*}$ To Marx the State was a historical product corresponding to a given form of society, altering according to the changes in the composition of this society, and disappearing with it when its day was done. Before, however, this could be arrived at, the State machinery was to be conquered by the workers and used for the purpose of carrying out their emancipation.

This was his original theory. Already in the sixties, we see him in the International oppose State omnipotence in matters of education. (See "Beehive", 14th and 21 st August, 1869.) The State was to make education compulsory, to ascertain that a fixed minimum of education was given, and to provide means and supervision in regard to efficiency. But education itself must be independent of State-tutorship, its management must be left to the municipalities or similar popular bodies.

In the famous pamphlet on the Paris Commune, Marx has more fully sketched out his ideas on the coming political organisation of society. There he declares bluntly that "the working class cannot simply lay hold of the ready-made State machinery and wield it for its own purpose". On the other hand, nothing would be more against the purpose than to break up the big nations into small independent states. "The unity of great nations", he writes, "if originally brought about by political force, has now become a powerful co-efficient of social production". It is not to be abolished. Through democratisation of local and municipal government, by increasing the functions and powers of local elected bodies, through a proper system of devolution and delegation of powers the state was to be changed into a real commonwealth - not a power above Society, but a tool in the hands of an organised Democracy.

For details I must refer to the third section of the said pamphlet itself. The whole is rather sketchy, and not all perhaps practicable. But it is also not meant as more than a general outline, to be corrected by experience.

* "Don't fear," says the resolution of the International on factory laws, "that you fortify governments if you support them in enforcing such laws. You make them your servants." 
One thing, however, is clear. You may call Marx whatever you like, you cannot call him after that a State idoliser and a fanatic for officialism.

And here I may also refer to the famous sentence, "Force is the midwife of old society in child-birth with a new society." A thousand times it has been quoted, and in 999 cases in the sense of an appeal to brute violence. But if we look to the passage where it is taken from, what examples of force do we find there? The Colonial systems, the funding system, modern taxation, the system of commercial protection. "Some of these methods", says Marx, "are based on brute force, as the Colonial system". "But all", he continues, "utilise the power of the State, the centralised and organised force of Society, to foster the process of evolution with hothouse vigour, and to shorten the transition periods". And then follows the sentence: "Force is the midwife of society", etc. It is quite evident, then, that it is, before all, the utilisation of the power of organised society Marx emphasises here, and not brute force. In the same spirit he describes (ch. 13 , sec. 9 of "Das Kapital") factory legislation as "the first conscious and systematic interference of society with the processes of production".

I lay stress on this point, not in order to whitewash Marx in the eyes of the Philistine, but because I think it only just to disconnect the cult of brute force and the unprovoked use of sanguinary phraseology from the name of Marx. Marx was by passion a revolutionary fighter, but his passion did not blind him to the teaching of experience. He admitted in 1872 that in countries like England it was possible to bring about the emancipation of the workers by peaceful means. To-day this is certainly still more the case, since the influence of the workers on the legislation has increased more than threefold. Not only societies, but also Socialists, have to learn.

In the Franco-German Annals, which Marx, together with the neoHegelian Ruge, started in 1844, there is printed a curious correspondence between Marx, Ruge, Bakounine, and some other men on the principles of their projected Review. In the concluding letter Marx says: -

Nothing prevents us from connecting our criticism with real struggles. We, then, don't appear before the world as doctrinaires with a new principle: Here is truth - here kneel down! We unfold to the world from its own principles new principles.

In the same year Marx became a convert to Socialism. He took it up in this realistic spirit, and overcame at once the then flourishing Utopianism. And in the same spirit he wrote after the downfall of the Commune: -

The working class did not expect miracles from the Commune. They have no ready-made Utopias to introduce par décret du peuple. They know that in order to work out their own emancipation, and along with it that higher 
form to which present society is irresistibly tending, by its own economic agencies, they will have to pass through long struggles, through a series of historic processes, transforming circumstances and men.

These words alone dispel the idea that Marx expected the realisation of a socialistic society from one great cataclysm. ${ }^{20}$

The term "social reform" is as equivocal as all political terms. We are all social reformers to-day: some in order to fortify present society, others in order to prepare the way for an easy and organic growth of a new cooperative society, based on common ownership of land and the means of production. And even amongst reformers in the latter sense some will prefer a more cautious policy, others a more impulsive action. But intentions alone do not decide the course of development, and in a given moment the impulsive reformer may have to choose between destroying the chance of a real step in advance, and thereby delaying the whole movement, or, by supporting people whose ways generally are not his, help the carrying out of such progressive measures. However strong Marx's sympathies were with the impulsive reformer, where an important step in the direction of lifting the social position of the workers was in question he would certainly not have hesitated to part ways with him if he refused to lend a hand.

ED. BERNSTEIN.

${ }^{20}$ Here the original speech probably ended. Apparently, the following paragraph was added to conclude the published article. 